〈農芸化学奨励萓〉

\title{
酸性 $\alpha$-グルコシダーゼの活性部位に関する反応速度論的研究
}

\author{
北海道大学農学部 松 井 博 和
}

酵素の持つ際立った特性の 1 つは，その特定の基 質に対してのみ有効に発揮される触媒機能である. 古くは，1つの醉素がただ一種の基質にのみ作用す るものと考えられていた。しかし，アミラーゼ類や プロテアーゼ類のように，作用を受ける部位を共通 に持つ一群を基質とするものも多い. $\alpha$ グルコシダ 一ゼはそのような酵素の典型といえる。この醉素は 生物界に広く存在し，その起源により基質特異性が 大きく異なる. 今日では, エキソ型に $\alpha$ グルコシド 結合を加水分解し， $\alpha$-グルコースを生成させる一群 の酵素を総称して $\alpha$-グルコシダーゼと呼んでいる.

本研究は動・植物, 微生物のグリコーゲンおよび 測粉の代謝上重要な位置にある酸性 $\alpha$-グルコシダ 一ゼに関し，基質特異性を速度パラメータを用いて 厳密に評価し，長年にわたる少糖と多糖の加水分解 部位の単一性に関する疑問を種々の反応速度論的方 法に基づいて解決するとともに，本醉素のほか幾つ かの関連グリコシラーゼについて反応機構の解析を 行ったものである。

\section{I. 基質特異性}

従来 $\alpha$-グルコシダーゼの特異性は, 基質のある一 定濃度に扔ける速度の比較でなされていた。 $\alpha$ グル コシダーゼはグルコアミラーゼと同様に $\alpha$ グルコ シド結合を水解してグルコースを生成するが, 前者 はおもに少糖（マルトースやマルトトリオースなど） によく作用し，多糖（溊粉やグリコーゲンなど）に は作用しないか，あるいは，その作用は弱いものと されていた，後者はその逆である．しかし，そのよ

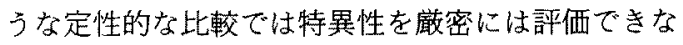
い.

著者は各種の哺乳動物(ブタの肝臟拉よび血清, ウサギの筋肉招よび肝臟)，植物(テンサイ，スウィ ートコーン，コメ，モチゴメ抢よびキビの未発芽種 子, トラマメ拈よびウズラマメの発芽種子等), 微生 物 (Asp. niger, Asp. oryzae, Paecilomyces varioti 等) から 20 種以上の $\alpha$-グルコシダーゼを均一な標 品にまで精製し，それらの一般的諸性質を明らかに するとももに, 少糖, 多桾, 合成基質等に対する特 異性を速度パラメーター $\left(K m, k_{0}, k_{0} / K m\right)$ を用い
て評価した。 その結果, 動物組織由来の酸性 $\alpha$-グル コシダーゼや植物起源 $\alpha$-ダルコシダーゼは, 少糖と 同様に多糖をもよく水解することを明らかにした。 とくに,テンサイ $\alpha$-グルコシダーゼのように高分子基 質によく作用するグルコアミラーゼ様 $\alpha$-グルコシ ダーゼの発見は，グリコシダーゼの分類上において も重要であり，生成物のアノマー分析の必要性があ らためて認識されることとなった。また，速度パラ メーターを用いての特異性の評価は各種起源醉素間 における直接的比較をも可能にし，さらに，サブサ イト理論を応用することにより，グルコアミラーゼ との相違も明確にすることができた。すなわち， $\alpha$ グルコシダーゼ間の多糖水解能の差異注第 4 番目以 降のサブサイト親和力に大きく影響されること， $\alpha$ グルコシダーゼとグルコアミラーゼ間では，いずれ においても第 2 番目のサブサイト親和力が最大であ るが，第 1 番目と第 3 番目のサブサイト親和力は, 前者では常に第 $1>$ 第 3 であるのに対し，後者では 第 1く第 3であることを明らかにした。

II. 酸性 $\propto$-グルコシダーゼの少糖と多糖水解部 位

哺乳動物の組織中には，酸性側に至適 $\mathrm{pH}$ を持つ

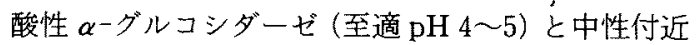
でよく作用する中性 $\alpha$ グルコシダーゼが存在する. 1963 年 Hersにより,グリコーゲン蓄積症 (Pompe 病または糖原病)が酸性 $\alpha$-グルコシダーゼの欠損に よることが明らかにされて以来, 本酵素による少桾 と多糖の水解が単一の活性部位で触媒されるのか, それとも，それぞれが別個の活性部位で触媒される のか大きな関心が持たれていた。これまで，幾つか の起源（ウサギ筋肉，ラット肝臟等）の䤏素でその ような検討がなされたが，満足すべき結論は得られ ていなかった。

そこで，ウサギ筋肉，ウサギ肝臓抢よびブタ肝臓 の酸性 $\alpha$-グルコシダーゼ,さらにテンサイ, コメ, スウィートコーン,トラマメ等の酸性側に至適 $\mathrm{pH}$ を持つ多くの植物 $\alpha$-グルコシダーゼについて,少糖 と多糖からなる混合基質系（マルトースとグリコー ゲン，あるいは，マルトースと澱粉）での速度論的 
解析，少糖と多糖水解における活性解離基の同定, 阻害剂や活性化剂の影響の解析，化学修飾法等に基 ついて活性部位の検討を行った。その結果，いずれ の酵素も低分子と高分子基質を単一の活性部位で水 解することを証明した。

混合基䡠系の実験で得られた結果の一例を図 1 に 示す。図中の $f=0$ は基質がグリコーゲンのみの, $f=1$ はマルトースのみの場合のプロットである. $f$ を 0.1 から 0.6 までのそれぞれのモル分率（ここで は非還元末端グルコース濃度の分率) で両者を混合 した場合, いずれのfのプロットも直線性を示し, かつ，両基質間の拮抗現象が認められた，各混合基 質系での速度パラメーターは，両基質が共通の活性 部位で加水分解されると仮定した場合の理論值によ く合致した。

酸性 $\alpha$-グルコシダーゼによる少糖および多糖の 水解反応に括いては，二種のカルポキシル基，すな わち- $\mathrm{COO}^{-}$と $\mathrm{COOH}$ が基質種に関係なく触媒作用 に直接寄与していることが， $\mathrm{p} K$ 值および解離熱の 剆定, 低誘電率培地での $\mathrm{p} K$ 值の変化の観測から判 明した，両基質水解反応で同じ活性解離基が関与す るということは，活性部位が共通であることを示唆 する。活性部位の検討とは別個に，ブタ肝臟および

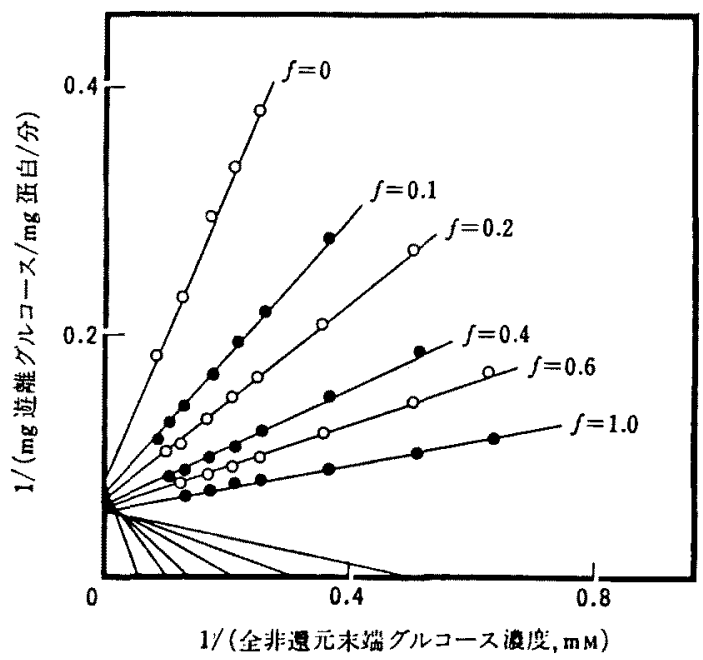

図 1 ウサギ肝葴酸性 $\alpha$-グルコシダーゼによるマルト ースーグリコーゲン混合基質系加水分解の両逆数 プロット

$f=($ マルトース)/(マルトース+グリコーゲン), すなわち基質の非還元末端グルコース濃度による モル分率を示す、各プロットは実験值、実線は両基 質が共通の活性部位で加水分解されると仮定した 場合の理論曲線。
血清の中性 $\alpha$-グルコシダーゼ, 中性域に至適 $\mathrm{pH}$ 持つビール酵母 $\alpha$-グルコシダーゼの反応解離基を 求め，カルボキシル基 $\left(-\mathrm{COO}^{-}\right)$とヒスチジンのイ ミダゾール基 (於 $\left.\mathrm{NH}^{+}\right)$が活性発現に必須な残基で あることを明らかにし，酸性 $\alpha$ グルコシダーゼとの 明確な相違を示した。

III. グリコシラーゼの新しい触媒能ととの機構

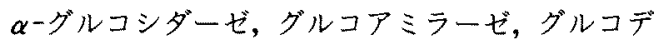
キストラナーゼ, トレハラーゼ等のいわゆるグりコ シラーゼが本来の $\alpha$-グルコシド結合を欠く特異な 基質にも作用することを示し，幾つかの酵素の反応 機構の解明を行った。

D-glucal はアノマー型を有さないプロキラル化 合物である，結晶 Asp. niger，コメ，テンサイ执よ びブタ血清 $\alpha$-グルコシダーゼはこれを基䝷とし，2 -deoxy-D-glucose を生ずることを明らかにした (図 2). この水和反応の立体化学を, $\mathrm{D}_{2} \mathrm{O}$ 中反応物 の'H-NMR 解析により調べたところ, プロトンは 面の上部 $(r e$-face) から入り，生成物は通常の $\alpha-ク ゙$ ルコシド結合を有する基質からの水解産物（ $\alpha$-グル コース)と同様に $\alpha$ 型であることがわかった，Arthrobacter globiformis のグルコデキストラナーゼ, Paecilomyces varioti およびRhizopus niveus $ク ゙$ ルコアミラーゼも同様に水和反応を触媒した。 これ らの酵素では下面 (si-face) よりプロトンが入り， $\beta$ 型の生成物を生じることが明らかになった。

結晶 Asp. niger とコメの $\alpha$-グルコシダーゼ，さ らに, Trichoderma reeseiのトレハラーゼは $\mathrm{D}^{-}$ gluco-octenitol を D-gluco-octulose に転換する水 和反応 (図 3)をも触媒することを明らかにした。本 基質も上記 $\mathrm{D}^{-}$glucal 同様プロキラル化合物であ る、反応による生成物のアノマ一型は, 前者からの ものは $\alpha$ 型, 後者からのものは $\beta$ 型であることを確 認した。

結晶Asp. niger，コメおよびテンサイ起源の $\alpha-$

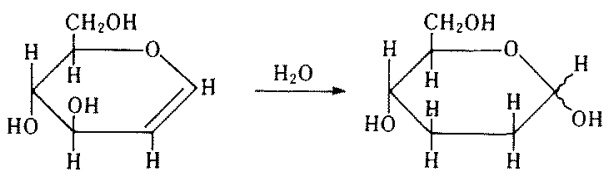

図 2 D-glucal の水和反庆

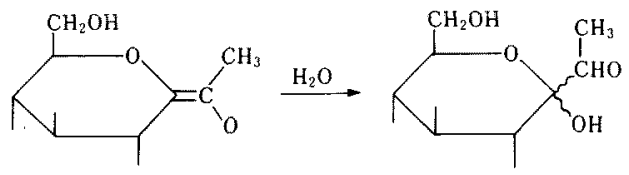

图 3 D-gluco-octenitol の水和反応 


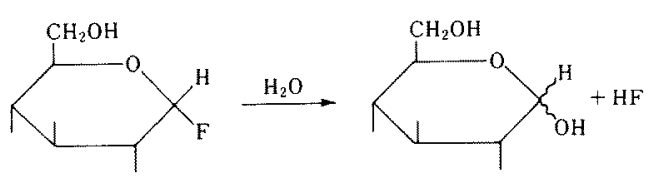

図 $4 \alpha$-D-glucosyl fluoride $\sigma$ C-F 切断反応

グルコシダーゼ, Rh. niveus, Asp. niger および Pae. varioti 起源のグルコアミラーゼ, A. globifor misのグルコデキストラナーゼは $\alpha$-D-glucosyl fluoride $の \mathrm{C}-\mathrm{F}$ 結合を切断することを見出した。す なわち，図40反応を触媒し， $\alpha$-グルコシダーゼの 反応では $\alpha$-グルコースが,グルコアミラーゼやグル コデキストラナーゼの反応では $\beta$-グルコースが生 ずる.同位元素置換体の基質を用いて，第 2 次アイ ソトーブ効㽤の有無を検討したところ，グルコアミ ラーゼやグルコデキストラナーゼの反応では明確な
置換効果が認められ，それらの反応がオキソカルボ ニウムイオン中間体を経て触媒されるものと推定し t:

終わりに臨み，本研究の遂行にあたり，終始ご指 導，ご鞭撻を賜りました北海道大学農学部千葉誠哉 教授に心から㧍礼申し上げます。研究の一部は、二 ューヨーク市アルバート・アインシュタイン医科大 学で行われたものであり，ご指導いただきました E. J. Hehre 教授, 共同研究者の静岡大学教育学 部岡田嚴太郎教授に深く感謝いたします。また，北 大農芸化学科生物化学講座, 本間守先生, 木村淳夫 先生，ならびに，当講座に打いて学を修められまし た多くの学生・院生諸氏の励ましのお言葉, 研究の ご協力に対し，厚くお礼申し上げます。 